\title{
SISTEM OTOMATISASI DRIP IRIGASI DAN MONITORING PERTUMBUHAN TANAMAN CABAI BERBASIS INTERNET OF THINGS
}

\author{
Atit Pertiwi $\left(\oplus^{1}\right)$, Veronica Ernita Kristianti $\left(^{2}\right)$, Ihsan Jatnita $\left(^{3)}\right.$, dan Ady Daryanto $(\overbrace{}^{4)}$ \\ ${ }^{1}$ Sistem Komputer, Universitas Gunadarma \\ ${ }^{2}$ Teknik Elektro, Universitas Gunadarma \\ ${ }^{3}$ Teknik Informatika, Universitas Gunadarma \\ ${ }^{4}$ Agroteknologi, Universitas Gunadarma \\ 1,2,3,4 Jl. Margonda Raya No. 100, Pondok Cina, Depok \\ E-mail : atit@staff.gunadarma.ac.id ${ }^{1}$, veronica@staff.gunadarma.ac.id ${ }^{2}$, ihsan@staff.gunadarma.ac.id ${ }^{3)}$, \\ adydaryanto@staff.gunadarma.ac.id ${ }^{4)}$
}

\begin{abstract}
ABSTRAK
Di masa depan akan sulit untuk menyediakan pasokan pangan segar dan bersih untuk populasi yang tumbuh cepat dengan tantangan lingkungan yang semakin berat jika hanya menggunakan teknik pertanian konvensional. Sistem monitoring tanaman dan irigasi tetes (drip irigasi) telah menunjukkan hasil yang menjanjikan di berbagai negara dan direkomendasikan sebagai sistem penanaman tanaman yang paling efisien, berguna, ekonomis serta nyaman dibandingkan metode produksi dengan media tanah atau teknik hidroponik sejenis. Optimalisasi sistem irigasi tetes tersebut dilakukan dengan menerapkan otomatisasi dalam pengukuran konsentrasi nutrisi, $\mathrm{pH}$ air, suhu/kelembaban udara dan intensitas cahaya serta pemantauan pertumbuhan tanaman dengan menggunakan Raspberry Pi dan IoT (Internet of Things). Tahapan yang dilakukan mulai dari perancangan perangkat keras, budidaya tanaman, perancangan basis data dan antar muka serta implementasi dan uji coba. Pengujian alat sistem monitoring pertumbuhan tanaman cabai berbasis web menujukkan monitoring dapat dilakukan terhadap pertumbuhan tanaman cabai, pemenuhan nutrisi dapat dilakukan secara otomatis, dan hasil pantauan tersimpan dalam web, baik data secara grafik, tabel dan juga dalam bentuk citra.
\end{abstract}

Kata Kunci: Drip irigasi, Hidroponik, Sensor, Raspberry Pi, Internet of Things (IoT)

\section{PENDAhuluan}

Populasi dunia saat ini diperkirakan sebanyak 7.2 miliar dan diproyeksikan akan terus meningkat hingga mencapai 8.1 miliar pada tahun 2025 dan 9.3 miliar pada tahun 2011 (Lee, 2011). Peningkatan pertumbuhan penduduk akan berkorelasi pada peningkatan permintaan atas pangan dan lahan pertanian. Selain itu, perubahan iklim global yang disebabkan oleh meningkatnya emisi gas $\mathrm{CO} 2$ akan meningkatkan risiko penurunan kualitas lingkungan dan kekeringan sehingga menjadi masalah serius pada produksi pertanian (Khan, I., Hou, F., \& Le, 2021). Oleh karena itu, diperlukan inovasi pada peralatan pertanian yang tepat waktu untuk mendukung budidaya pertanian khususnya pada wilayah-wilayah pertanian yang mengalami kelangkaan air yang sering terjadi akibat pertumbuhan penduduk dan perubahan iklim.

Cabai merupakan komoditas hortikultura unggulan Nasional yang memiliki nilai ekonomi tinggi. Terdapat 2 spesies cabai yang ditanam luas di Indonesia yaitu, cabai merah (Capsicum annuum L) dan cabai rawit (Capsicum frutescens L.) (KEMENTAN, 2021), sedangkan cabai gendut (Capsicum pubescens L.) hanya ditanam di dataran tinggi seperti dataran tinggi Dieng (Yamamoto, S., Djarwaningsih, T., \& Wiriandinata, 2013). Menurut (FAOSTAT, 2019) Indonesia bersama dengan China, Meksiko, dan Turki menjadi empat negara produsen cabai terbesar di dunia. Produktivitas cabai di Indonesia pada tahun 2019 hanya 8.67 ton $^{-1}$ (KEMENTAN, $^{-}$ 2021) sedangkan produktivitas cabai di China di tahun yang sama dapat mencapai 23.83 ton ha ${ }^{-1}$ (FAOSTAT, 2019). Rendahnya produktivitas tersebut salah satunya disebabkan rendahnya teknologi pengairan pada budidaya cabai.

Ketersediaan air menentukan keberhasilan produksi tanaman, baik secara vegetatif maupun generatif karena air merupakan kebutuhan dasar bagi tanaman. Pengaturan jumlah dan waktu pemberian air akan mendukung keberhasilan budidaya tanaman karena air adalah media pengangkut nutrisi/hara dari media tanam ke seluruh bagian tanaman. Namun kelebihan dan kekurangan air mengganggu tanaman karena dapat menghambat pertumbuhan dan perkembangan tanaman serta mempengaruhi produksi tanaman (Supriadi, D. R., Susila, A. D., \& Sulistyono, 2018). Budidaya tanaman dengan sistem irigasi tetes dilaporkan memiliki keunggulan dalam efisiensi pemakaian air dan pemeliharaan tanaman (Nora, S., Yahya, M., Mariana, M., Herawaty, H., \& Ramadhani, 2020).

Tanaman cabai membutuhkan ketersediaan air dalam jumlah yang cukup serta tepat waktu. Keadaan tersebut dapat dicapai dengan penerapan sistem irigasi tetes (drip irigasi). Sistem irigasi tetes dapat mengatur jumlah dan 
waktu pemberian, sesuai dengan kebutuhan air tanaman bagi tanaman cabai. Irigasi tetes telah diterapkan pada budidaya cabai baik pada lingkungan terkontrol seperti rumah kaca dan juga lahan pertanian terbuka khususnya pada saat musim kemarau (Nur, K. M., Haq, E. S., \& Suwardiyanto, 2020). Total penggunaan air selama masa pertumbuhan tanaman tomat dengan sistem drip irigasi adalah $500-600 \mathrm{ml}$ atau mampu menghemat penggunaan air hingga $90 \%$ dari total penggunaan air tanpa sistem drip irigasi (Setyaningrum, D. A., Tusi, A., \& Triyono, 2014).

Teknologi monitoring diperlukan dalam rangka mendukung metode irigasi yang mampu mengendalikan pemberian air serta pemupukan secara efektif dan efisien. (Nur, K. M., Haq, E. S., \& Suwardiyanto, 2020) melaporkan efektifitas perangkat monitoring otomatis berupa sensor kelembapan dan nutrisi tanaman yang sesuai dengan kebutuhan tanaman cabai. Berdasarkan hal tersebut, dinilai penting untuk mampu menghadirkan teknologi irigasi yang dapat dipantau kapan saja tanpa harus pergi ke tempat atau lapangan. Sehingga dapat mendorong penciptaan produk berkualitas dan juga penghematan penggunaan air.

Dengan diterapkannya teknologi otomatisasi dan IoT pada Drip irigasi, aktivitas monitoring nilai konsentrasi nutrisi, $\mathrm{pH}$, suhu/kelembaban udara dan intensitas cahaya dari sensor serta kondisi pertumbuhan tanaman dengan menggunakan kamera dapat dilakukan dengan jarak jauh. Data hasil identifikasi sensor konsentrasi nutrisi, PH, suhu/kelembaban udara dan intensitas cahaya dan data citra pertumbuhan tanaman dikendalikan oleh Raspberry pi lalu dikirim ke server untuk disimpan pada basis data dan ditampilkan melalui website. Selain itu, pengontrolan system irigasi tetes dapat dilakukan secara otomatis dengan interval waktu tertentu. Dengan inovasi pembelajaran ini diharapkan dapat mendorong mahasiswa lebih kreatif dalam menuangkan ide-ide yang inovatif pada sistem IoT di bidang pertanian.

\section{RUANG LINGKUP}

Ruang lingkup dalam penelitian ini adalah merancang alat sistem monitoring tanaman secara otomatis menggunakan Raspberry Pi dan berbasis IoT (Internet of Things).

Penelitian ini merancang dua sistem yaitu perangkat keras dan basis data. Monitoring dilakukan dengan beberapa sensor, yaitu sensor kelembaban, sensor $\mathrm{pH}$, sensor nutrisi, sensor intensitas cahaya, dan sensor kamera. Seluruh sensor terintegrasi ke Raspberry Pi sebagai pusat kendali. Penelitian ini juga melakukan budidaya tanaman cabai yang akan digunakan untuk objek dalam pengujian alat sistem monitoring yang dibuat. Monitoring dilakukan dalam 6 pot tanaman cabai. Hasil monitoring terhubung ke website. Data tanaman cabai yang terbaca pada sensor seluruhnya tampil dalam website, baik dalam bentuk tabel dan juga dalam bentuk grafik. Berdasarkan hasil pengujian rancangan alat sistem monitoring tanaman berbasis IoT menggunakan Raspberry Pi dapat terlihat pada website.

\section{BAHAN DAN METODE}

Bahan-bahan dan metode yang digunakan dalam penelitian ini dijelaskan sebagai berikut:

\subsection{Raspberry Pi}

Raspberry $\mathrm{Pi}$ adalah board komputer kecil yang bekerja pada sistem operasi Linux yang terhubung ke monitor komputer, keyboard, dan mouse. Raspberry Pi dapat diterapkan pada struktur elektronik dan kerja jaringan pemrograman, juga dapat berfungsi sebagai komputer pribadi dan Apache Webserver, MySQL dapat diinstal di board. Pin GPIO dapat digunakan sebagai input digital atau output digital, dan keduanya beroperasi pada 3.3V. Berbeda dengan Arduino, Raspberry Pi tidak memiliki input analog. Hal ini membuat Raspberry Pi harus menggunakan external analog-to-digital converter (ADC) atau menghubungkan Pi ke interface board yang harus digunakan (Buckseth, T., Sharma, A. K., Pandey, K. K., Singh, B. P., \& Muthuraj, 2016). Raspberry Pi ditunjukkan pada Gambar 1.

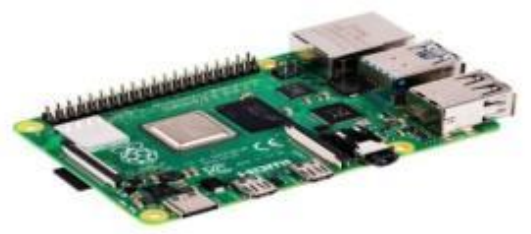

Gambar 1. Raspberry Pi

\subsection{Sensor DHT11, pH, EC (Electrical Conductivity), LDR (Light-Dependent Resistor)}

Sensor DHT11 memiliki 3 pin, satu pin sebagai output dan dua pin digunakan untuk membaca secara analog kelembaban dan temperature suhu. Sensor DHT11 digunakan juga untuk mengukur suhu dan kelembaban udara untuk sistem pertanian hidroponik (Jindarat, S., \& Wuttidittachotti, 2015). Petani dapat memantau suhu dan kelembaban ruangan dalam sistem hidroponik kapan pun dan dimana pun dengan menggunakan sensor DHT11 yang diintegrasikan dengan Raspberry Pi 3 dan memanfaatkan API Telegram Messenger. Sensor DHT11 ditunjukkan pada Gambar 2.

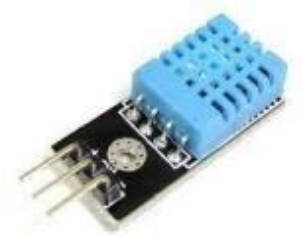

Gambar 2. Sensor DHT11

Sensor DHT11 memiliki fitur yang kompleks karena dapat mendeteksi suhu dan kelembaban dengan keluaran digital yang terkalibrasi. Modul DHT11 bekerja pada 
komunikasi serial yaitu komunikasi kabel tunggal. Modul ini mengirimkan data berupa rangkaian pulsa periode waktu tertentu. Interface serial kabel tunggal membuat integrasi sistem menjadi cepat dan mudah. Ukurannya kecil, konsumsi daya rendah, dan transmisi sinyal hingga 20 meter menjadikannya pilihan terbaik untuk berbagai aplikasi, termasuk untuk diaplikasikan dalam bidang pertanian (Mutyalamma, A. V., Yoshitha, G., Dakshyani, A., \& Padmavathi, 2020).

Potential Hydrogen $(\mathrm{pH})$ meter adalah alat yang digunakan untuk mengukur tingkat keasaman dan kebasaan dalam air, tanah dan bahan kimia (Sisyanto, R. E., \& Kurniawan, 2017). Pada dasarnya $\mathrm{pH}$ meter terdiri dari voltmeter yang dipasang pada elektroda responsif $\mathrm{pH}$ yang bervariasi antara rentang 0 hingga 14. Sensor pH yang digunakan ditunjukkan pada Gambar 3.

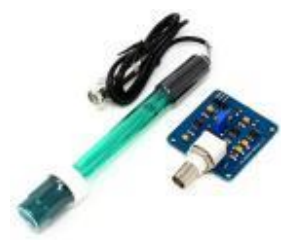

Gambar 3. Sensor pH

$\mathrm{pH}$ meter terdiri dari dua elektroda, elektroda kaca dan elektroda referensi. Elektroda kaca berisi larutan $\mathrm{KCl}$ yang merupakan larutan netral dengan $\mathrm{Ph}$ 7.pH meter mengubah beda potensial antara permukaan dalam dan luar elektroda kaca menjadi nilai pH (Srivastava, D., Kesarwani, A., \& Dubey, 2018).

Sensor EC (Electrical Conductivity) adalah alat yang mengukur daya hantar listrik dalam suatu larutan. Ini biasanya digunakan dalam sistem hidroponik, akuakultur, dan air tawar untuk memantau jumlah nutrisi, garam, atau kotoran di dalam air (Pawar, P. A., \& Phatangare, 2019), sensor EC ditunjukkan pada Gambar 4. Nilai standar sensor EC yang baik untuk sistem hidroponik adalah $0.9-2.1 \mathrm{mS} / \mathrm{cm}$ (Alexopoulos, A. A., Marandos, E., A., A., Vidalis, N., Petropoulos, S. A., \& Karapanos, 2021).

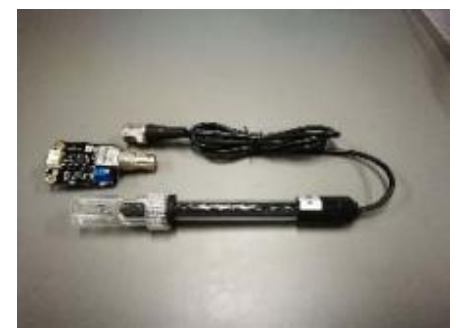

Gambar 4. Sensor EC

Pemantauan intensitas cahaya pada hidroponik dilakukan dengan menggunakan LDR. Petani dapat memantau kondisi cahaya pada sistem hidroponik, kapan pun dan dimana pun, yang dilakukan adalah memanfaatkan API Telegram Messenger Merancang CPSS yang terintegrasi dengan sistem hidroponik menggunakan Raspberry Pi 3 yang dihubungkan dengan modul Light Dependent Resistor (LDR) (Jindarat, S., \& Wuttidittachotti, 2015).

Light-dependent resistor (LDR) adalah resistor variabel yang dikendalikan cahaya. Resistansi LDR menurun dengan meningkatnya intensitas cahaya insiden, sensor ditunjukkan pada Gambar 5.

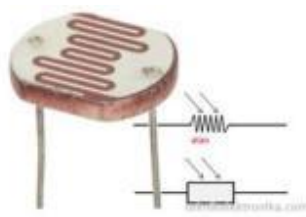

Gambar 5. Sensor LDR dan simbol

Modul sensor memiliki kenop potensiometer untuk mengatur nilai ambang batas kecerahan cahaya. LED terpasang menyala saat cahaya sekitar lebih besar dari nilai ambang batas. Jika intensitas cahaya sekitar lebih besar dari nilai ambang batas maka pin DO menghasilkan nilai LOW(0) dan ketika intensitas cahaya sekitar kurang dari nilai ambang batas, DO mengeluarkan nilai TINGGI(1) (Srivastava, D., Kesarwani, A., \& Dubey, 2018).

\subsection{Kamera Raspberry Pi}

Modul Raspberry Pi dapat diintegrasikan dengan modul kamera, hal ini dimanfaatkan untuk memantau tanaman secara real time (Ruengittinun, S., Phongsamsuan, S., \& Sureeratanakorn, 2017). Kamera Raspberry Pi adalah kamera kecil definisi tinggi berdaya rendah yang dilengkapi dengan pada kabel fleksibel yang akan dihubungkan ke konektor CSI (Camera Serial Interface) (Alipio, M. I., Cruz, A. E., Doria, J. D., \& Fruto, 2017). Kamera Raspberry Pi ditunjukkan pada Gambar 6.

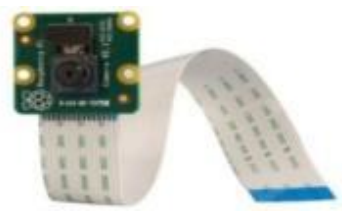

Gambar 6. Kamera Raspberry Pi

\subsection{Internet of Things (IoT)}

Internet of Things (IoT) adalah paradigma komunikasi revolusioner yang memainkan peran penting dalam bidang pemantauan jarak jauh dan operasi kontrol. Sistem pemantauan dan kontrol jarak jauh berbasis IoT berpotensi memecahkan masalah sosial di bidang kesehatan, lingkungan, otomatisasi rumah, transportasi, militer, agrikultur, pengolahan limbah padat, pengawasan, pelacakan, sistem komunikasi kendaraan dan pemantauan dalam waktu bersamaan (Ramson, S.R. Jino, S. Vishnu, 2020). 


\subsection{Perancangan Sistem}

Perancangan sistem otomatisasi drip irigasi dan monitoring tanaman cabai digambarkan pada Gambar 7 .

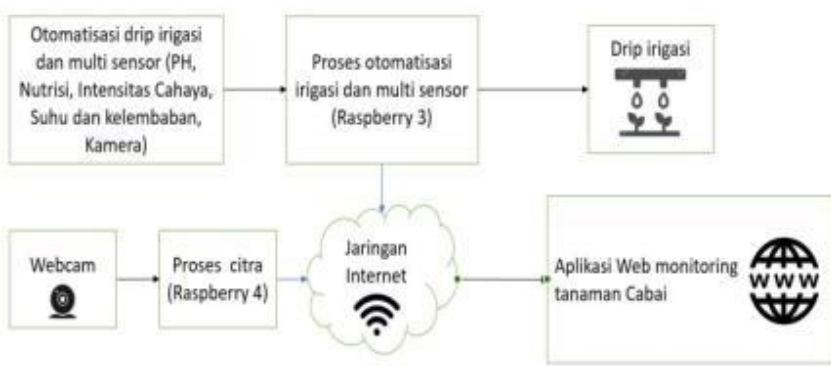

Gambar 7. Perancangan Sistem Otomatisasi Drip Irigasi dan Monitoring Tanaman Cabai Berbasis IoT

Otomatisasi drip irigasi, menggunakan dua buah pompa peristaltik untuk memompa nutrisi A dan nutrisi B serta pompa DC mini digunakan untuk memompa air yang keduanya akan dialirkan ke dalam wadah campuran nutrisi dan air. Pada wadah campuran nutrisi dan air dipasang sensor ultrasonik (HC-SR04) untuk mendeteksi ketinggian air, sensor nutrisi (DFRobot SENO244) untuk mendeteksi kepekatan nutrisi, dan sensor $\mathrm{pH}$ (pH-4502C) untuk mengukur kadar $\mathrm{pH}$ air dan nutrisi dalam wadah. Pengaturan aliran air ke pot tanaman menggunakan kran DC solenoid. Sensor suhu (DHT-11) berfungsi untuk mengukur suhu dan kelembaban lingkungan lokasi tanaman. Sensor intensitas cahaya (BH1750) berfungsi untuk mengukur intensitas cahaya lingkungan lokasi tanaman. Data hasil identifikasi multi sensor $(\mathrm{pH}$, nutrisi, suhu, dan intensitas cahaya) di proses oleh Raspberry Pi 3 dan hasil luaran dikirim ke database web melalui jaringan internet serta ditampilkan pada aplikasi web monitoring tanaman. Monitoring pertumbuhan tanaman menggunakan kamera untuk memantau pertumbuhan tanaman dengan menangkap gambar tanaman. Hasil tangkapan gambar akan disimpan pada Raspberry Pi 4 dan dikirimkan secara real-time melalui jaringan internet dan ditampilkan pada aplikasi web monitoring tanaman. Berdasarkan penjelasan tersebut, skematis rancangan alat ditunjukkan pada Gambar 8.
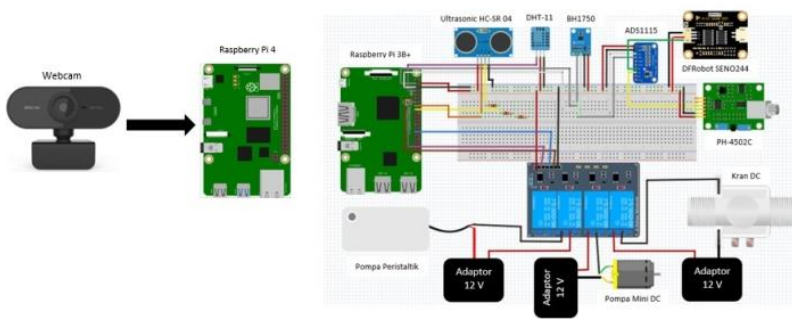

Gambar 8. Skematis Alat Sistem Otomatisasi Drip Irigasi dan Monitoring Tanaman Cabai Berbasis IoT

Sistem monitoring yang dibangun dalam penelitian ini berbasis IoT dan dijelaskan pada Gambar 9. Flowchart sistem menjelaskan bahwa ketika program
"MULAI" selanjutnya memastikan terlebih dahulu apakah sistem diberi tegangan, jika "Tidak" maka program akan langsung selesai, jika "Ya" maka sensor Ultrasonik, sensor suhu dan kelembaban, sensor Intensitas cahaya, sensor nutrisi dan sensor PH akan aktif mendeteksi objek sekitarnya. Kemudian data yang diperoleh dari semua sensor tersebut diproses di dalam Raspberry Pi 3B.

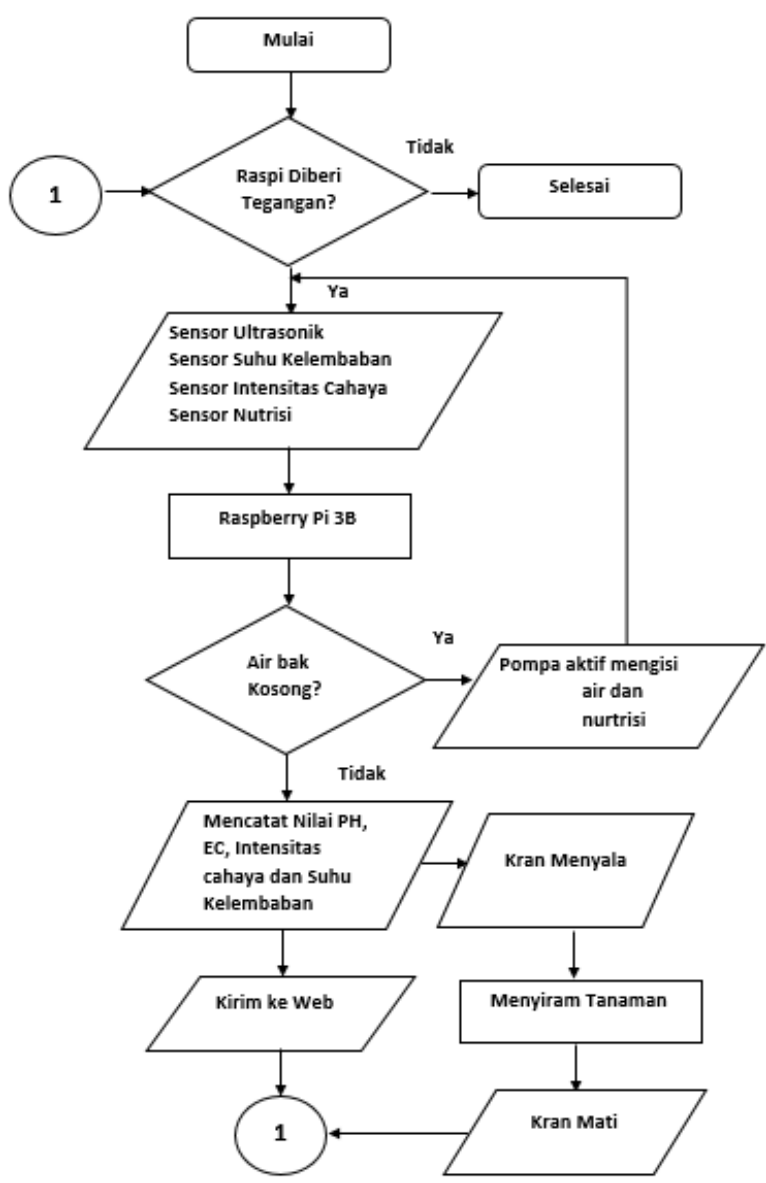

Gambar 9. Flowchart Sistem IoT Monitoring Tanaman

Pada proses terdapat kondisi "apakah air bak kosong?" (pada Raspberry Pi telah diatur jarak sensor ultrasonik dan permukaan air wadah lebih dari $12 \mathrm{~cm}$ ). Jika "Ya" (lebih dari $12 \mathrm{~cm}$ ) maka pompa aktif mengisi air dan nutrisi kemudian terjadi pengulangan proses program kembali. Akan tetapi, jika "Tidak" (jarak kurang dari $12 \mathrm{~cm}$ ) maka sistem akan membaca nilai $\mathrm{PH}$, EC, Intensitas Cahaya, suhu dan kelembaban. Selanjutnya data yang diperoleh dikirim ke web serta kran akan terbuka atau menyala otomatis.

Pada saat kran menyala kemudian air akan mengalir menyirami tanaman. Setelah melakukan proses penyiraman tanaman kran akan otomatis mati atau tertutup. Sistem ini akan terus melakukan perulangan program selama Raspberry Pi masih menerima tegangan. 
Selain perancangan perangkat keras, penelitian ini juga merancang basis data dan aplikasi guna menyimpan dan menampilkan data pada website. Perancangan sistem ini menggunakan basis data untuk menyimpan 5 jenis nilai data. Setiap nilai data berasal dari alat sensor yang berbeda serta kamera. Nilai dari setiap sensor disimpan dalam Tabel 1.Tabel ini digunakan untuk menyimpan data suhu yang berasal dari sensor kelembaban, data dari sensor $\mathrm{pH}$ tanah, data dari sensor nutrisi, data dari sensor intensitas cahaya, dan waktu pengambilan data.

Tabel 1. Tabel Data Sensor

\begin{tabular}{|c|c|c|}
\hline Nama Field & Tipe Field & Keterangan \\
\hline KodeArea & VarChar(3) & Kode untuk tanaman yang diamati \\
\hline NilaiSuhu & Numbers & $\begin{array}{c}\text { Menunjukkan nilai suhu tanaman, } \\
\text { berupa bilangan riil }\end{array}$ \\
\hline NilaiPH & Numbers & $\begin{array}{c}\text { Menunjukkan nilai PH tanah, } \\
\text { berupa bilangan riil }\end{array}$ \\
\hline NilaiNutrisi & Numbers & $\begin{array}{c}\text { Menunjukkan nilai konsentrasi } \\
\text { nutrisi, berupa bilangan riil, } \\
\text { dengan satuan ppm }\end{array}$ \\
\hline NilailC & Numbers & $\begin{array}{c}\text { Menunjukkan nilai intensitas } \\
\text { cahaya, berupa bilangan riil }\end{array}$ \\
\hline Timestamp & Datetime & $\begin{array}{c}\text { Menunjukkan waktu pengambilan } \\
\text { data }\end{array}$ \\
\hline
\end{tabular}

Monitoring tanaman cabai yang dilakukan dalam penelitian ini juga dilakukan pengambilan gambar, dalam basis data juga dirancang untuk penyimpanan citra hasil capture dari sensor kamera, dan dijelaskan pada Tabel 2.

Tabel 2. Tabel Citra

\begin{tabular}{|c|c|c|}
\hline $\begin{array}{c}\text { Nama } \\
\text { Field }\end{array}$ & Tipe Field & Keterangan \\
\hline KodeArea & Varchar(3) & Kode untuk tanaman yang diamati \\
\hline NamaFile & Varchar & $\begin{array}{c}\text { Menunjukkan nama file citra hasil } \\
\text { tangkapan kamera. }\end{array}$ \\
\hline Timestamp & Datetime & $\begin{array}{c}\text { Menunjukkan waktu pengambilan } \\
\text { data }\end{array}$ \\
\hline
\end{tabular}

Perancangan aplikasi ini terdiri dari 6 menu yaitu Beranda, Data Suhu, Data PH, Data Nutrisi, Data Intensitas Cahaya, dan Data Citra. Pada menu Beranda, aplikasi akan menampilkan ringkasan dari seluruh data monitoring berupa rata-rata nilai setiap jenis data selama masa pengamatan, dan grafik gabungan 4 jenis data. Rancangan menu Beranda dapat dilihat pada Gambar 10.

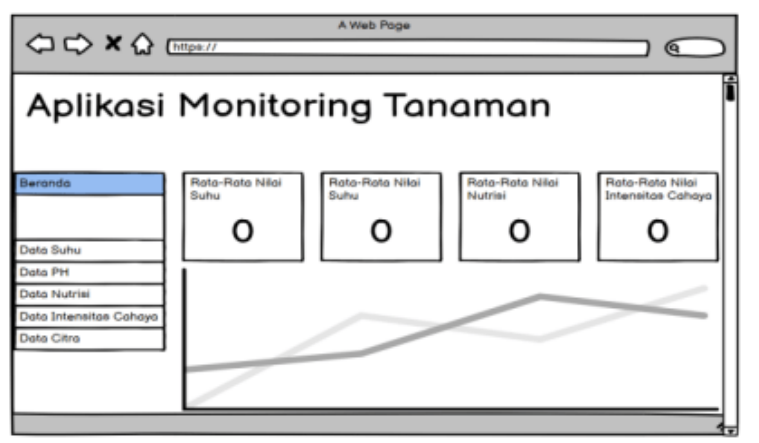

Gambar 10. Menu Beranda
Menu lainnya kecuali menu Data Citra, akan menampilkan data nilai hasil pengamatan dalam dua bentuk yaitu dalam bentuk grafik garis dan dalam bentuk tabel. Sebagai contoh untuk menu Data Suhu, bentuk grafik dapat dilihat pada Gambar 11, dan bentuk tabel dapat dilihat pada Gambar 12. Menu Data Citra akan menampilkan daftar citra dalam bentuk thumbnail hasil penangkapan kamera beserta tanggal dan waktu penangkapan. Untuk melihat citra dalam ukuran yang lebih besar pengguna dapat klik salah satu thumbnail citra yang diinginkan. Rancangan antar muka dapat dilihat pada Gambar 10 sampai Gambar 13.

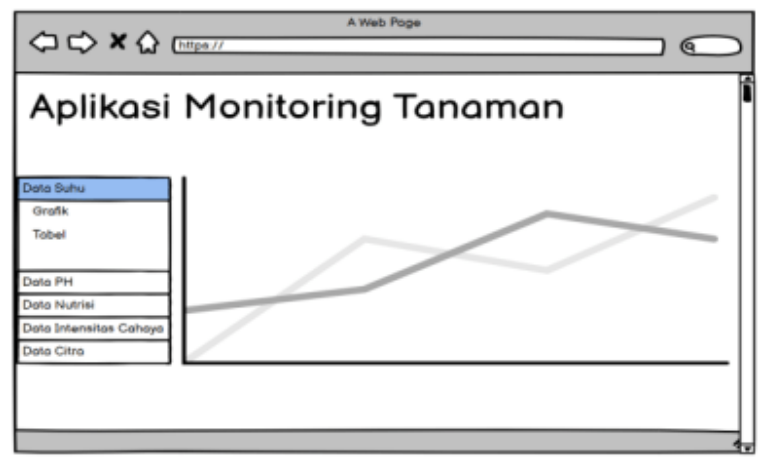

Gambar 11. Menu Data Suhu - Grafik

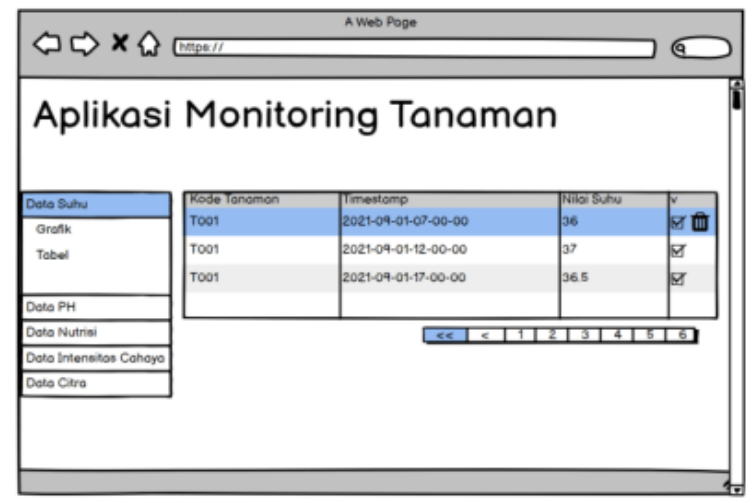

Gambar 12. Menu Data Suhu - Tabel

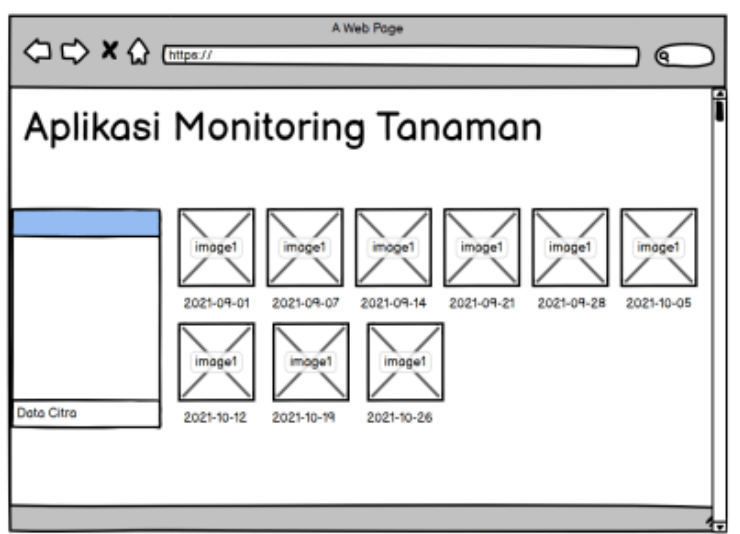

Gambar 13. Menu Data Citra 
Data suhu, PH air, nutrisi, intensitas cahaya dan citra hasil capture tanaman dapat dipantau melalui aplikasi web monitoring tanaman.

Selain perancangan perangkat keras dan basis data, dilakukan juga budidaya terhadap tanaman cabai yang menjadi objek dalam penelitian ini. Gambar 14 dan Gambar 15 adalah proses persemaian tanaman cabai menggunakan media campuran cocopeat dan arang sekam dengan perbandingan $1: 1(\mathrm{v} / \mathrm{v} 1: 1)$ di dalam tray semai ukuran 72 sel. Bibit cabai yang telah memiliki daun $4-6$ helai atau berumur 5 minggu setelah semai (MST) dipindahkan ke dalam pot berukuran $20 \mathrm{~cm}$ menggunakan komposisi media yang sama seperti saat persemaian.

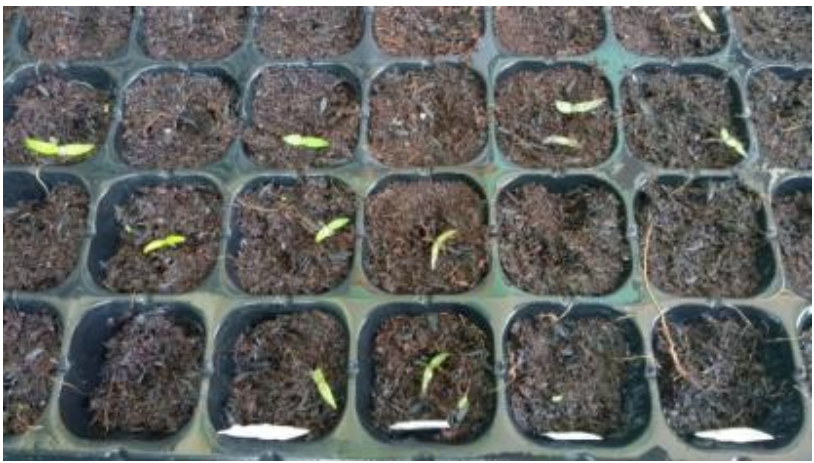

Gambar 14. Persemaian Benih Cabai Menggunakan Tray Semai Berukuran 72 Sel.

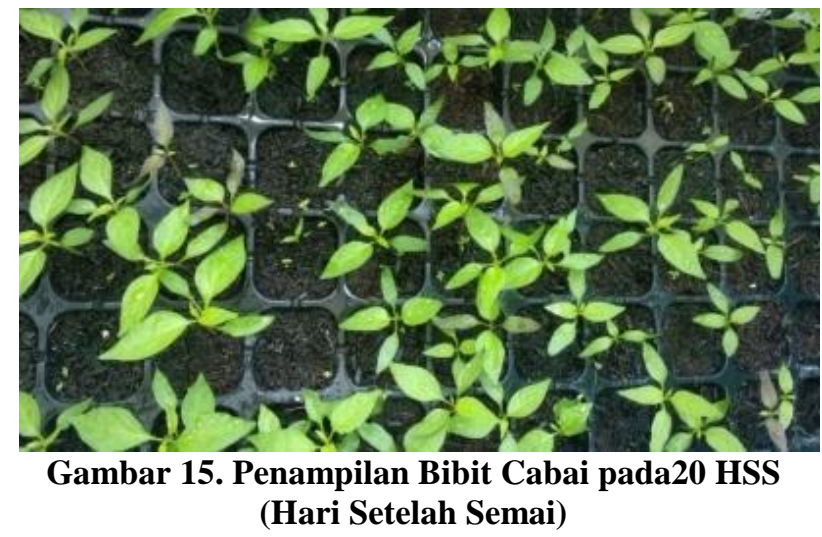

\section{PEMBAHASAN}

Sistem monitoring pertumbuhan tanaman cabai pada penelitian ini terdiri dari 2 perancangan, yaitu perancangan perangkat keras dan perancangan basis data dan aplikasi. Perangkat keras pada sistem ini terdiri dari sistem drip irigasi, perancangan sistem nutrisi, sistem
Pemantauan kondisi lingkungan dan perancangan pengkabelan. Gambar arsitektur perancangan dapat dilihat pada Gambar 16. Komponen utama pada perancangan ini adalah Raspberry $\mathrm{Pi} 3 \mathrm{~B}+$ sebagai pengontrol komponen - komponen elektronika dan Raspberry PI 4 B+ berfungsi untuk mengontrol kamera dan servo (penggerak kamera).

Data citra yang dihasilkan kamera digunakan untuk memantau pertumbuhan tanaman. Sensor konsentrasi nutrisi, berfungsi untuk mengukur kadar nutrisi pada air, sehingga tanaman akan mendapatkan nutrisi dengan takaran yang tepat. Sensor $\mathrm{pH}$ air digunakan untuk mengukur tingkat keasaman dan kebasaan air pada tandon. Sensor suhu untuk memantau suhu dan kelembaban lingkungan tanaman. Sensor Cahaya digunakan untuk mengukur intensitas cahaya pada ruangan sistem hidroponik dan aeroponik. Data hasil identifikasi sensor akan dikirim ke server dan di tampilkan pada website. Begitupun dengan data citra akan dikirimkan ke server dan ditampilkan dengan interval waktu tertentu. Proses pemberian nutrisi terhadap tanaman dilakukan dengan system irigasi tetes secara otomatis dengan interval waktu tertentu.

Hasil monitoring pertumbuhan tanaman berdasarkan sensor suhu dan kelembaban udara ditunjukkan pada Gambar 17. Sensor suhu dan kelembaban yang digunakan adalah sensor DHT-11.

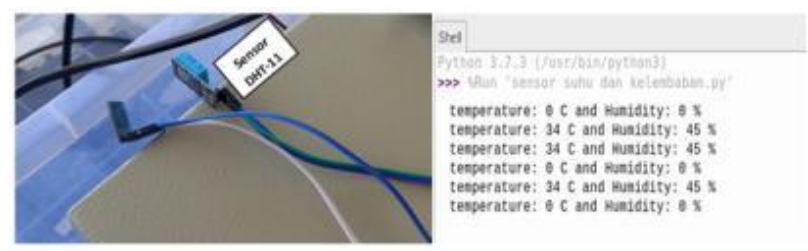

\section{Gambar 17. Hasil Monitoring Sensor Suhu dan Kelembaban Udara}

Tanaman cabai membutuhkan suhu sekitar $18^{\circ} \mathrm{C}$ sampai $30^{\circ} \mathrm{C}$ dan kelembaban $60 \%$ sampai $80 \%$. Pada percobaan didapatkan hasil dari sensor DHT-11 yaitu rata-rata temperature $34^{\circ} \mathrm{C}$ dan kelembaban $45 \%$, sehingga lokasi tempat percobaan ini tidak cocok untuk penanaman tanaman cabai.

Gambar 18 menjelaskan hasil monitoring sensor intensitas cahaya pada monitoring tanaman cabai. Sensor yang digunakan adalah sensor BH1750. 


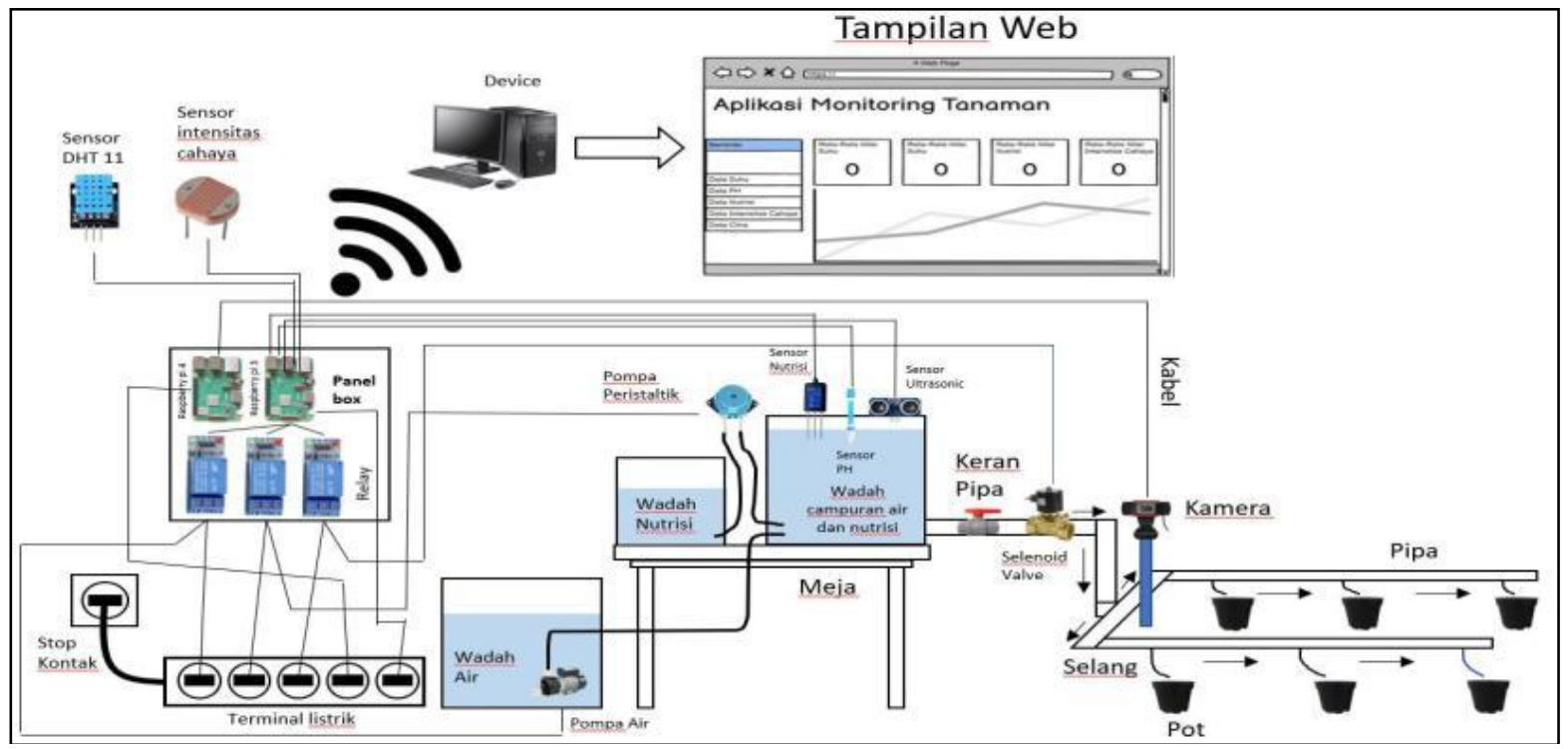

Gambar 16. Arsitektur Perancangan Sistem Monitoring Pertumbuhan Tanaman Cabai
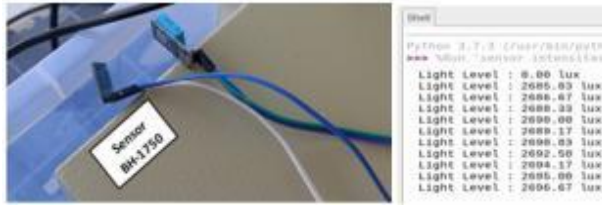

Gambar 18. Sensor Intensitas Cahaya

Tanaman cabai membutuhkan intensitas cahaya 2658 lux sampai 4287 lux. Pada Percobaan didapatkan hasil dari sensor BH1750 yaitu rata-rata 2690 lux sehingga lokasi tempat percobaan ini cocok untuk penanaman tanaman cabai dari segi intensitas cahayanya.

Pengujian pada sensor $\mathrm{pH}$ campuran nutrisi dan air ditunjukkan pada Gambar 19.

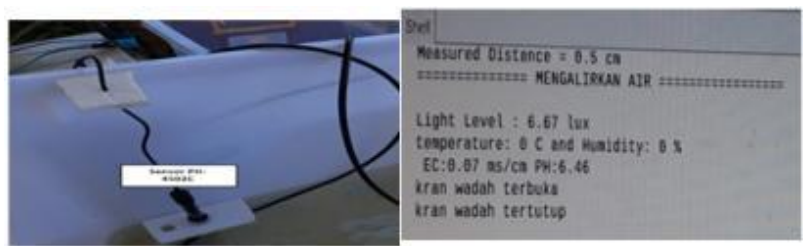

Gambar 19. Sensor pH Campuran Nutrisi dan Air

Pengujian Sensor PH-4502C dilakukan untuk mendapatkan hasil dari PH suatu cairan. Untuk tanaman cabai membutuhkan PH 6,0 sampai 6,5.

Gambar 20 menunjukkan sensor nutrisi yaitu sensor DFRobot SENO244, dilakukan untuk mendapatkan hasil kepekaan nutrisi suatu cairan.

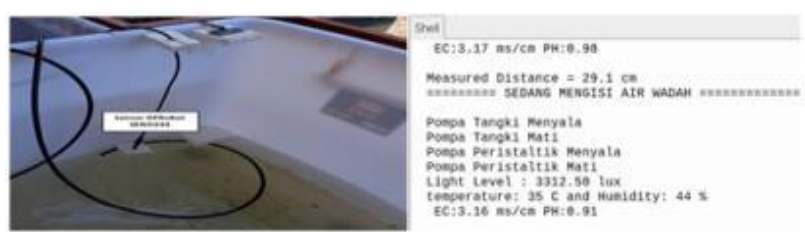

Gambar 20. Sensor Nutrisi
Tanaman cabai membutuhkan kepekatan nutrisi sebesar 2,4 mS/cm sampai 2,6 mS/cm. Pengujian Sensor HC-SR04 dilakukan untuk membaca jarak permukaan air dari sensor ultrasonik ditunjukkan Gambar 21.

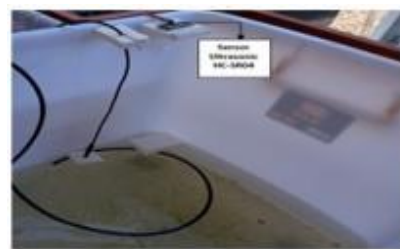

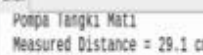
Measured Distance $=29.1 \mathrm{co}$ Ponpa Tangk kat I Neasured Distance $=29.2 \mathrm{ca}$ Ponpa Tergkd Kati Measured Distance $=3.2 \mathrm{ct}$ Poope Tergkt Kenyala

\section{Gambar 21. Sensor Ketinggian Campuran Nutrisi dan Air}

Apabila jarak permukaan air dari sensor ultrasonik lebih dari $12 \mathrm{~cm}$ maka pompa air mini dan pompa peristaltik akan mengisi wadah. Akan tetapi jika jarak permukaan air dari sensor ultrasonik kurang dari $12 \mathrm{~cm}$ maka kran solenoid akan terbuka untuk mengalirkan air ke tanaman.

Sistem monitoring pertumbuhan tanaman cabai dalam penelitian ini juga menerapkan sistem otomatisasi pada pompa air, nutrisi dan irigasi tetes yang dijelaskan pada Gambar 22

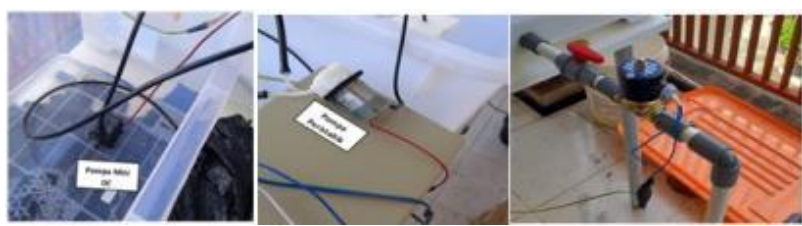

Gambar 22. Otomatisasi Pompa Air, Nutrisi dan Irigasi Tetes

Hasil pemantauan pertumbuhan tanaman berdasarkan sistem IoT yang diterapkan dalam penelitian ini, yang 
tersimpan dalam basis data dan tersimpan serta dapat ditampilkan pada website, ditunjukkan pada Gambar 23.

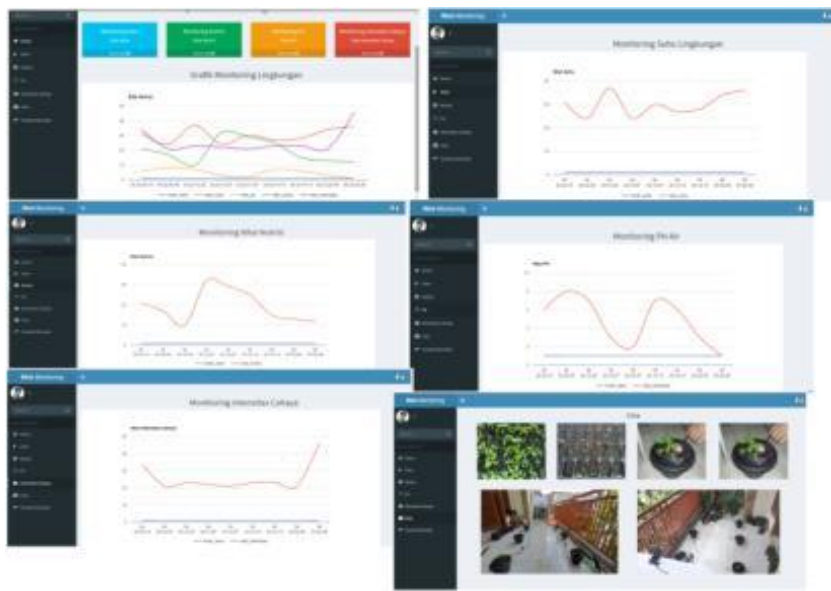

Gambar 23. Data Hasil Pemantauan Tanaman Cabai pada Website

Web monitoring ini dapat menampilkan seluruh pengamatan sensor yang digunakan dan ditampilkan dalam bentuk grafik. Tampilan citra hasil tangkapan dari sensor kamera juga tersimpan dan dapat ditampilkan dalam website. Data hasil pantauan ini dapat menjadi pantauan.

\section{KESIMPULAN}

Perancangan sistem monitoring pertumbuhan tanaman cabai berbasis IoT dengan menggunakan Raspberry Pi dalam penelitian ini menunjukkan bahwa pemantauan dapat dilakukan dan seluruh sistem dapat bekerja secara otomatis seperti yang telah ditentukan dalam perancangan. Hasil pemantauan dapat terhubung ke website, sehingga dapat dilakukan analisis terhadap pertumbuhan tanaman cabai berdasarkan data-data hasil pemantauan. Pengembangan penelitian ini selanjutnya adalah menambahkan sensor pendeteksi ketinggian dan pembuatan machine learning untuk mendeteksi penyakit/hama pada tanaman.

\section{SARAN}

Monitoring tinggi tanaman cabai juga penting dilakukan karena tinggi tanaman merupakan salah satu kriteria yang menentukan tanaman tersebut tumbuh dengan sehat dan subur. Monitoring dilakukan dengan menambahkan sensor pendeteksi tinggi tanaman. Selain itu, hama/penyakit tanaman adalah salah satu faktor yang menjadi penyebab gagal panen atau tanaman mati. Pencegahan yang harus dilakukan adalah dengan membuat sistem monitoring yang dapat mendeteksi adanya hama/penyakit tanaman.

\section{DAFTAR PUSTAKA}

Alexopoulos, A. A., Marandos, E., A., A., Vidalis, N., Petropoulos, S. A., \& Karapanos, I. C. (2021). Effect of Nutrient Solution $\mathrm{pH}$ on the Growth,
Yield and Quality of Taraxacum officinale and Reichardia picroides in a Floating Hydroponic System. Agronomy, 1118.

Alipio, M. I., Cruz, A. E., Doria, J. D., \& Fruto, R. M. (2017). A smart hydroponics farming system using exact inference in Bayesian network. In In 2017 IEEE 6th Global Conference on Consumer Electronics (GCCE) (pp. 1-5).

Buckseth, T., Sharma, A. K., Pandey, K. K., Singh, B. P., \& Muthuraj, R. (2016). Methods of pre-basic seed potato production with special reference to aeroponics-A review. Scientia Horticulturae, 79 87.

FAOSTAT. (2019). Food and Agriculture Organization of The United Nations. Diambil kembali dari Countries by commodity.

Jindarat, S., \& Wuttidittachotti, P. (2015). Smart farm monitoring using Raspberry Pi and Arduino. In In 2015 International Conference on Computer, Communications, and Control Technology (I4CT) (pp. 284-288).

KEMENTAN. (2021). Diambil kembali dari Basis data statistik pertanian. Retrieved from https://www.pertanian.go.id/home/?show=page\&a $\mathrm{ct}=$ view\&id $=61$

Khan, I., Hou, F., \& Le, H. P. (2021). The impact of natural resources, energy consumption, and population growth on environmental quality: Fresh evidence from the United States of America. Science of the Total Environment, 754.

Lee, R. (2011). The outlook for population growth. Science, 333(6042), 569-573.

Mutyalamma, A. V., Yoshitha, G., Dakshyani, A., \& Padmavathi, B. V. (2020). Smart Agriculture to Measure Humidity Temperature Moisture $\mathrm{Ph}$. and Nutrient Values of the Soil using IoT. International Journal of Engineering and Advanced Technology (IJEAT).

Nora, S., Yahya, M., Mariana, M., Herawaty, H., \& Ramadhani, E. (2020). Teknik Budidaya Melon Hidroponik dengan Sistem Irigasi Tetes (Drip Irrigation). AGRIUM: Jurnal Ilmu Pertanian, 2126.

Nur, K. M., Haq, E. S., \& Suwardiyanto, D. (2020). Penerapan Teknologi Automatic Drip Irrigation System (ADIS) Untuk Meningkatkan Produktivitas Cabai Di Banyuwangi. In Prosiding Seminar Nasional Terapan Riset Inovatif (SENTRINOV) (pp. 1185-1191).

Pawar, P. A., \& Phatangare, V. S. (2019). Sensor Data Acquisition in Smart Farming using Wireless Sensor Network Technology. International Journal of Trend in Research and Development, 20-22.

Ramson, S.R. Jino, S. Vishnu, M. S. (2020). Applications of Internet of Things (IoT) - An Overview. In 2020 5th International Conference on Devices, Circuits and Systems (ICDCS) (pp. 
92-95).

Ruengittinun, S., Phongsamsuan, S., \& Sureeratanakorn, P. (2017). Applied internet of thing for smart hydroponic farming ecosystem (HFE). In $n 2017$ 10th International Conference on Ubi-media Computing and Workshops (Ubi-Media) (pp. 1-4).

Setyaningrum, D. A., Tusi, A., \& Triyono, S. (2014). Aplikasi Sistem Irigasi Tetes pada Tanaman Tomat ((Lycopersicum esculentum Mill). Jurnal Teknik Pertanian Lampung, 3(2), 127-140.

Sisyanto, R. E., \& Kurniawan, N. B. (2017). Hydroponic smart farming using cyber physical social system with telegram messenger. In In 2017 International conference on Information technology systems and innovation (ICITSI) (pp. 239-245).

Srivastava, D., Kesarwani, A., \& Dubey, S. (2018). Measurement of Temperature and Humidity by using Arduino Tool and DHT11. International Research Journal of Engineering and Technology
(IRJET), 876-878.

Supriadi, D. R., Susila, A. D., \& Sulistyono, E. (2018). enetapan Kebutuhan air tanaman cabai merah (Capsicum annuum L.) dan cabai rawit (Capsicum frutescens L.). Jurnal Hortikultura Indonesia, 3846.

Yamamoto, S., Djarwaningsih, T., \& Wiriandinata, H. (2013). Capsicum pubescens (Solanaceae) in Indonesia: its history, taxonomy, and distribution. Economic Botany, 67(2), 161-170.

\section{UCAPAN TERIMA KASIH}

Penelitian ini bisa terlaksana berkat kesempatan yang telah diberikan oleh beberapa pihak diantaranya, Task Force PPKM - MBKM Universitas Gunadarma Tahun 2021 melalui dana penelitian yang diberikan dan juga Mara Nugraha, S.Kom., M.M.S.I yang telah memberikan arahan selama perancangan sistem. 